\section{Gringinal Communitations.}

\author{
ON THE INDICATIONS FOR THE ENPLOY OF \\ MERCURY IN PRIMARY SYPHILITIC SORES:
} AND ON THE SO-CALLED “ SPECIFIC INDURATION."

By Langstox Parker, Esq., Surgeon to the Queen's Hospital, Birmingham.

I $\Delta x$ desirous of correcting, through the medium of the Azsociation Medical Jodrnal, an error to which publicity has been given in an original article, published by $\mathrm{Mr}$. Henry Lee in the October number of the British and Foreign Medico-Chimurgical Review. The point in question refers to the indications for the employ of mercury in primary venercal sexual sores. It is exceedingly probable that what I wished to be understood has not been expressed in language sufficiently clear; and this I cndeavoured to correct in a clinical lecture, published in the Association Jodroul for March 185j. That lecture contains iny doctrine, as clearly expressed as I know how to express it, in reference to this important subject.

With regard to the point more immediately in question, I say " that the employ of mercury specifically is indicuted in cases of well marked indurated chancre; ${ }^{*}$ but this would have been better cxpressed if I had said, in sores presenting a well marked "sub-chancrous induration."

Again, I say "that this indication is still more pressing, if such sores are accompanied by bubo." What I mean here is, that when such sores are, as they most commonly are, accompanied by distinct enlargement of one or more glands in one or both groins, which glands are hard and tender, but which have not suppurated, and do not apparently contain matter, the use of mercury is still more strongly indicated.

I do not mean, and never said, "in suppurating bubo"; for, without believing implicitly in the dogma of Ricord and his school on this point, it is well known that a bubo which suppurates at all freely is not commonly followed by secondary symptoms, though this is not true in all cases; and, in such instances, it would be well to wait for the appearance of secondary symptoms before mercury is employed at all.

I use the term "sub-chancrous" induration, as synonimous with the so-called "specific induration" of a primary syphilitic ulcer. By it I mean a hard lump, movable under the skin, which comes on between four and fourteen days after the first appearance of the ulcer; this induration is situated under the sore, or at one side of the sore, and at time it appears the glands of one or both groins become hard and tender, but very rarely suppurate. This specific induration, or sub-chancrous induration, is the transition state between the local and the constitutional disease, and marks the commencement of constitutional infection.

There is another condition of a primary syphilitic ulcer to which the term "induration" has been applied; and it is of the first importance to distinguish between these two.

After the continuance of a primary ulcer for a longer or shorter period of time, it frequently happens that its edges become hard and elevated, surround it as it were by a little hard ring; or the skin upon which it is situated, and which at first was perfectly healthy, becomes infiltrated with serum or lymph, and thus elevates or raises the sore higher than the surrounding parts. This infiltration or exudation renders the skin or tissues in the neighbourhood of the sore more or less hard; and such a condition might be confounded with specific induration, from which it very widely differs. And it is in this sense that some modern authors have said that all primary syphilitic ulcers were more or less indurated.

- The Modern Treatment of Syphilitic Disesses, otc., Srd odit, p. 15.
Should the glands of one or both groins become affected in the latter case, it is exceedingly probable that they will pass on to suppuration $\rightarrow$ circumstance that very rarely happens in the first instance.

Mercury is not necessarily required in the treatment of the second form of ulcer. It is, horrever, frequently of great use in removing the inflammatory deposit surrounding the sore; and here I believe it acts much in the same way that it does in removing inflammatory deposits of lymph effused in other situations, and produced by other causes.

\section{(}

REMARKS ON THE CLIMATE OF THE PERSIAN GULF ; WITH A GLANCE AT THE CHIEF DISEASES PREVALENT THERE; AND A BRIEF ACCOUNT OF THE PRINCIPAL PLACES ON THE COASTS.

By W. J. Moore, Esq., Assistant. Surgeon H.E.I.C.S., in Medical charge of the H. C. steam frigate Punjaub; formerly Senior Resident Surgeon to the Queen's Hospital at Birminghain, etc.

Ar the present time, when there is every probability of an expeditionary force proceeding from Bombay to the Persian Gulf, it would appear that a short description of the principal ports on that sea, with a passing notice of the class of diseases most prevalent there, would not be without interest to the readers. of the Association MEDical JodRNAL.

It is foreign to $\mathrm{my}$ intention even to point at the political reasons which have led to this display of force against the Shah of Persia ; but it will by this time be generally known in England that extensive preparations for war are being made at the Presidency of Bombay.

The situation of that remarkable arm of the sea, known to us as the Persian Gulf, is so familiar to all, that it would be unnecessary to say anything on that point. It may not, however, be so generally known that, for the last thirty years or so, constant employment has been found in this sea for a small squadron of British vessels. The Arabian coast was formerly peopled by a set of piratical Arabs, whose means of existence consisted in aitacking and plundering any Buggalow Pattimar, or other country craft, whose trading adventures took them into the vicinity of these said Arabs. Numerous vessels from the coast of Cutch, the ports of the Red Sea, India, Madagascar, and even from China, are constantly passing up and down the Gulf during the fair season. These, being unarmed, present an easy prey to the well armed and manned Arab grabs. Scarcely a season passes even now without the resident at Bushire having to despatch a ship of war to call one or other of these petty chiefs to account for some piracy committed on the high seas, or for continuing the now illegal slave trade. During the month of December 1855, the ship in which the writer was then serving, the brigantine of war Tigris, was despatched to a place in the southern part of the Gulf, named Abothabee, for the purpose of domanding from the sheikh of that place indemnification for the plunder of a native vessel sailing under the British flag.

The general climate of the Gulf may first be mentioned. About the middle of Octoher, the heats which prevailed during the previous months begin to moderate. In November it becomes still cooler, while during December and January it is positively cold, the mercury remaining during the day at $76^{\circ}$ or $80^{\circ}$ Fahrenheit, and in the night frequently sinking to $40^{\circ}$, and in the upper part of the Gulf even lower than that. There are no regular monsoon rains; but about the end of October, generally the 28 th or 29 th, rain falls in torrents, immediately preceded by much wind und clouds of sand and dust. In a day or two it generally clears up, and remains fine for some weeks, after which there are accidental showers and rainy days, as in the summer in England. At this time also, north- 